\title{
Women's Movements and Democratic Space in Yogyakarta (The Movement Strategies and Tactics of PKBI DIY and Needle and Bitch Community)
}

\author{
Ratnawati \\ ratnaugm@ugm.ac.id \\ Universitas Gajah Mada
}

\begin{abstract}
This research discusses about the strategies and tactics of the womens movement in seizing the repression of democratic space in Yogyakarta. The subjects in this study are 2 (two) woman organizations namely Perkumpulan Keluarga Berencana Indonesia (PKBI) Daerah Istimewa Yogyakarta (DIY) and Needle and Bitch. The purpose of this research is to understand the internal dynamics, external dynamics, and strategy of the social movement struggle especially womens movement in Yogyakarta. The method which utilised in this study is qualitative method by comparative case study with in-depth interviews and participatory observation. The findings of this study shows that the womens movement that has a professional organisational structure is more inclined to use the moderate method by empowering the affected groups; while the womens movement that has participatory organisational structure is more inclined to use the radical method by mobilising the masses to defend the democratic space. The implications of the womens movement strategy in the new democratic struggle to realise the importance of seizing the democratic spaceonly reach out to individuals and groups within the scope of the movement. The democratic struggle by the womens movement in the future requires to strengthen the network of the pro-democracy movement in the effort for the changes in the wider range.
\end{abstract}

Keywords: Womens Movement, Social Movement Strategy, Democracy.

\section{Introduction}

This research project investigates how women's movements have seized democratic space in Yogyakarta. Talking about such movements is not a matter of simply talking about gender issues [1]. The problems of democracy are also part of these movements' agendas [2] , and given these conditions, participation in the struggle for democracy is an important element of women's movements [3].

This research examines the strategies and tactics used by the women's movements PKBI DIY and Needle and Bitch community in challenging repression in the democratic space in Yogyakarta in 2016. To examine these movements' strategies and tactics, the writer examines cases in which democratic space was repressed in 2016. Such cases of repression were conducted by civilian militia groups (paramilitary and religious fundamentalists) who attempted to limit the democratic spaces and infringe on the fundamental rights of groups they perceived to violate the norms and rules of majority society. Such cases pose a severe threat to democracy, 
as intimidation, discrimination, and violence experienced is used against minority groups by militias claiming to represent general society. To examine this issue, this article applies the concepts of social movement typology and movement strategies.

\section{Methods}

This research is qualitative, using the comparative case study method. The case study method is intended to examine the phenomena, realities, and facts found in the field, thereby enabling the researcher to identify and delineate the complex aspects of the case discussed. The comparative method, meanwhile, is used for analysis and involves comparing and contrasting different research subjects to identify their similarities and differences [4].

The subjects of this research are the women's movements Perkumpulan Keluarga Berencana Indonesia (Indonesian Family Planning Association, PKBI) Yogyakarta and Needle and Bitch Community. These two women's movements were selected because of their different tendencies as women's movement as well as their opposition to the repression of democratic space in Yogyakarta. PKBI is a movement that attempts to address and advocate issues related to sexual and reproductive health and rights. Meanwhile, Needle and Bitch Community is a newer movement that exhibits radical tendencies in its presentation of sexuality, gender, and democracy issues. This research examines the strategies and tactics used by these two women's movements in seizing the democratic spaces that have been repressed by civil militias, with a focus on the cases that occurred in Yogyakarta in 2016.

Data was collected through the interview and documentation techniques. Data analysis used a qualitative approach.

\section{Results}

\subsection{Cases of Democratic Space being Repressed in Yogyakarta in 2016}

In 2016, there were many cases of democratic space being repressed in Yogyakarta. These included: (a) LGBT and Anti-LGBT demonstrations at Tugu, (b) closure of the Waria Al-Fatah Islamic Boarding School in Bantul, (c) intimidation of protesters on Malioboro Street, (d) dispersal of Ladyfast 2016 in Kasihan, (e) intimidation at the MAP Discussion Corner UGM on the '1965 National Symposium', (f) banning of the student publication PoroS at Ahmad Dahlan University, (g) cancellation of the screening of Pulau Buru Tanah Air Beta at Gadjah Mada University, (h) cancellation of the screening of Pulau Buru Tanah Air Beta at the Alliance of Independent Journalists, (i) Papuan Students Demonstration at the Kamasan Dormitory, (j) removal of billboards for Sanata Dharma University and Duta Wacana Christian University, and (k) intimidation at the KBR Alliance's International Human Rights Day commemoration at the city center.

This repression did not manifest only in frictions between different social groups, but also the forced dispersal and even attacks on certain gatherings by civil militia groups. Over the course of 2016, numerous cases showed that democracy in Yogyakarta is vulnerable and that various social groups have had their freedoms limited. These incidents were rooted in a range of issues; the most prominent were LGBT and Communism issues, while freedom of expression, freedom of opinion, and freedom of association were also involved. Available democratic 
spaces were used widely for the contestations of reactionary militia groups and pro-democracy movements. In 2016, cases of repression occurred almost monthly, taking the form of intimidation, forced dispersal, attack, and threats, making the democracy in Yogyakarta less than comfortable. This led to further clashes between militias and groups who felt their rights were being impugned.

\subsection{Types of Women's Movements}

Based on available data and information, PKBI may be listed as a professional movement. This is evidenced by its existing structure, division of functions, registration with the government, and members' full use of their time and energies for the movement and its activities. Further proof is PKBI's stable funding, which has given it the power to set its agenda and continue its struggles.

Needle and Bitch community, meanwhile, may be categorized as a participative movement, based on its lack of organizational structure, characteristic dependence on individual members, and self-identification as a campaign group or collective. Furthermore, Needle and Bitch Community lacks stable funding, an important factor as the availability of funds ensures that the movement is sustainable. Indeed, we can see that PKBI has been sustained until the present day owing to its organizational stability and funding (which enable its programs to be implemented regularly), while Needle and Bitch Community has ebbed and flowed both as an organization and its activities.

However, the activities and initiatives of Needle and Bitch Community show an incredible passion, as the movement's initiatives are followed by rapid organization and massive participation. A professional organization such as PKBI, meanwhile, has sustained regular interest, as expected for an organization that has long been involved in and organized its local community.

The experiences of these two movements may offer a reference for other organizations, and thereby contribute an understanding of the context where democratic space is repressed. Repression is more commonly accepted by members of grassroots organizations. Such repression is targeted mainly at people who are already vulnerable and who are not protected by a structured organization (i.e. a professional movement). Lacking legal protection, participative grassroots movements lack power when dealing with the state apparatus or with reactionary militia groups.

Meanwhile, the experiences of professional organizations are obtained through members who are organizing or supporting the development of grassroots organizations. This often occurs, but does not directly involve the movement organizationally. Over time, professional organizations are relatively safer. This is caused by their caution in dealing with opposing groups, especially as related to the issues they are fighting for. It is this degree of vulnerability that distinguishes professional organizations such as PKBI from participative organizations such as Needle and Bitch community.

\subsection{Strategies used by PKBI and Needle and Bitch Community to seize democratic space in Yogyakarta}

\section{a. Strategies Used by PKBI}

Based on data collected during an interview with Purwantining Tyas Wuri, a PKBI DIY staff member on September 11, 2016, to seize democratic space in Yogyakarta the organization has used the following strategies: 
To promote internal capacity building, PKBI has (1) conducted internal discussions regarding the repression of democratic space. These discussions were held to examine cases of repression within the context of protecting reproductive and sexual rights, and intended to increase cadres' awareness of the issue and share members' knowledge to create discourse within PKBI. Discussions have been held by PKBI since cases of repression first began occurring a few years previously. These discussions produced discourse that was then disseminated to counter the discourses of reactionary groups. Meanwhile, for non-gender issues, PKBI has supported other organizations by disseminating discourses from allied groups; (2) holding training courses for volunteers and socializing with local communities and partner organizations. Meanwhile, advocacy and propaganda strategies have included (1) holding public discussions that examine democracy issues from a reproductive and sexual rights perspective; (2) holding audiences with the government to discuss repression of democratic spaces; (3) choosing community organizers within partner organizations and affected communities, functioning to develop and guide these groups' empowerment; (4) providing services to victims of repression and violence, with a focus on psychological issues and traumas; (5) disseminating discourses through socialization, PKBI media, and community media/radio. In its networking strategies, meanwhile, PKBI has worked together with organizations with similar visions and missions. It seeks partners that have positive effects, use peaceful means, and avoids interacting/partnering with organizations that violate human rights.

\section{b. Strategies used by Needle and Bitch Community}

Meanwhile, based on data collected through interviews with the Needle and Bitch Community members Yudhistira and Pramilla Deva on 26 September 2016, the organization has used the following strategies to seize democratic space in Yogyakarta:

In developing its internal capacity, Needle and Bitch Community has used the following strategies (1) sharing knowledge regarding gender and democracy issues, and (2) providing selfdefense training to individuals so they can defend their rights in cases of violence and intimidation. Meanwhile, in its advocacy and propaganda activities, Needle and Bitch Community has used the following strategies: (1) producing handicrafts as propaganda that convey specific social messages; (2) disseminating alternative discourses through zines and digital media to voice their opinions, works, and attitudes; (3) opening shared spaces together with 'marginalized' individuals through Needle and Bitch Community activities as well as softskill training. In its networking strategies, Needle and Bitch Community has prioritized cultural proximity, prioritizing networks with groups that have realistic strategies and considering organizational culture and sustainability. It has also considered culture in creating sustainable partnerships with other organizations.

\section{Conclusion}

The strategies used by women's movements to seize space in democracy are determined by these movements' types. Professional women's movements tend to use more comprehensive strategies to seize democratic spaces than participative ones. As a result, the strategies of women's movements as they seek to promote democracy have only reached individuals and groups within the democracy movement who have an existing awareness of the importance of space. As such, in their democratic struggles these women's movements must reinforce their pro-democracy networks as they promote change at a broader scale. 
Acknowledgments. Researchers would like to thank Faculty of Social and Political Sciences, and Political and Government Departement, Universitas Gajah Mada for provide financial support fot this paper. The researcher is also grateful to all those who have supported and participated in the research process.

\section{References}

[1] F. Ridjal, Dinamika Gerakan Perempuan di Indonesia. Yogyakarta: Tiara Wacana Yogya, 1993.

[2] S. Wieringa, Penghancuran Gerakan Perempuan: Politik Seksual di Indonesia Pasca Kejatuhan PKI. Yogyakarta: Galang Press, 2010.

[3] M. Rini, "Feminisme: Antara Represi Gender dan Agenda Emansipatoris," Wacana, vol. 7. 1997.

[4] S. Arikunto, Manajemen Penelitian. Jakarta: Proyek Pengembangan LPTK, 1989. 